Al WASATH Jurnal Ilmu Hukum Volume 1 No. 2 Oktober 2020: 79-86

\title{
PENGUATAN HUKUM PENGADAAN BARANG DAN JASA PEMERINTAH UNTUK MEMPERCEPAT PEMBANGUNAN INDONESIA
}

\author{
Muhammad Rusydi \\ Mahasiswa Ilmu Hukum Universitas Nahdlatul Ulama Indonesia \\ muhammadrusydidr@gmail.com
}

\begin{abstract}
A B S T R A K
Pembangunan infrastruktur Indonesia telah menjadi prioritas utama pemerintah. Hal ini berkesinambungan dengan upaya pertumbuhan ekonomi yang terus dipacu selama lima tahun. Tercatat satu tahun pergantian pemerintahan, Pertumbuhan Ekonomi Indonesia bertumbuh sekitar 4,73\% di September 2015. Pembangunan infrastrukur yang terus dipacu tersebut haruslah didukung oleh sebuah legal standing yang kuat demi mempercepat pembangunan. Saat ini telah ada aturan terbaru mengenai hukum pengadaan barang dan jasa pemerintah, yakni Peraturan Presiden Nomor 16 tahun 2018 tentang Pengadaan Barang dan Jasa Pemerintah, akan tetapi melihat urgensi dan kebutuhan di lapangan, keberadaan Peraturan Presiden nomor 16 tahun 2018 perlu diganti dengan jenis peraturan yang lebih dari sekedar Peraturan Presiden. Pergantian tersebut bisa saja dirubah yang dahlunya adalah Peraturan Presiden menjadi sebuah Undang-Undang tentang pengadaan Barang dan Jasa Pemerintah. Penguatan Hukum pengadaan Barang dan Jasa Pemerintah akan menjadi pondasi yang kuat untuk mempercepat pembangunan yang merupakan salah satu prioritas pemerintah Indoesia.
\end{abstract}

Kata kunci: Pengadaan Barang dan Jasa Pemerintah, Infrastruktur, Peraturan

\section{A B S T R A C T}

Indonesia's infrastructure development has become the government's top priority. This is continuous with the efforts of economic growth that has continued to be driven for five years. One year of change of government recorded, Indonesia's Economic Growth grew about 4.73\% in September 2015. The development of infrastructure that continues to be driven must be supported by a strong legal standing to accelerate development. At present there is a new regulation regarding the law on procurement of government goods and services, namely Presidential Regulation Number 16 of 2018 concerning Procurement of Government Goods and Services, but seeing the urgency and needs in the field, the existence of Presidential Regulation number 16 of 2018 needs to be replaced with the type of regulation more than just a Presidential Regulation. The substitution could have been changed, which was originally a Presidential Regulation into a Law on the procurement of Government Goods and Services. Legal Strengthening the procurement of Government Goods and Services will be a strong foundation to accelerate development which is one of the priorities of the Indonesian government. 
Penguatan Hukum Pengadaan Barang Dan Jasa Pemerintah Untuk Mempercepat Pembangunan Indonesia

Keywords: Integrity, Anti-corruption, Partisipation dan Colaboration.

\section{P E N D A U U U A N}

\subsection{Latar Belakang}

Pembangunan infrastruktur Indonesia telah menjadi prioritas utama pemerintah. Hal ini berkesinambungan dengan upaya pertumbuhan ekonomi yang terus dipacu selama beberapa tahun ini. Tercatat satu tahun pergantian pemerintahan, ${ }^{1}$ pertumbuhan Ekonomi Indonesia bertumbuh sekitar 4,73\% di September 2015. Pembangunan infrastrukur yang terus dipacu tersebut haruslah didukung oleh sebuah legal standing yang kuat demi mempercepat pembangunan.

Demi memastikan proses pembangunan tersebut telah banyak berbagai macam aturan yang terbit. Perubahan aturan-aturan tersebut dimaksud untuk menjawab tantangan dan perubahan pola pengadaan yang selama ini terjadi. Perubahan aturan tersebut kemudian berubah hanya pada sisi materil saja. Namun, jika bicara penguatan hukum secara subtansi hukum tidak berubah sama sekali.

Setidaknya secara sederhana dan secara umum terdapat beberapa perubahan peraturan-peraturan mengenai pengadaan barang dan jasa pemerintah yang terlihat seperti gambar di bawah ini:

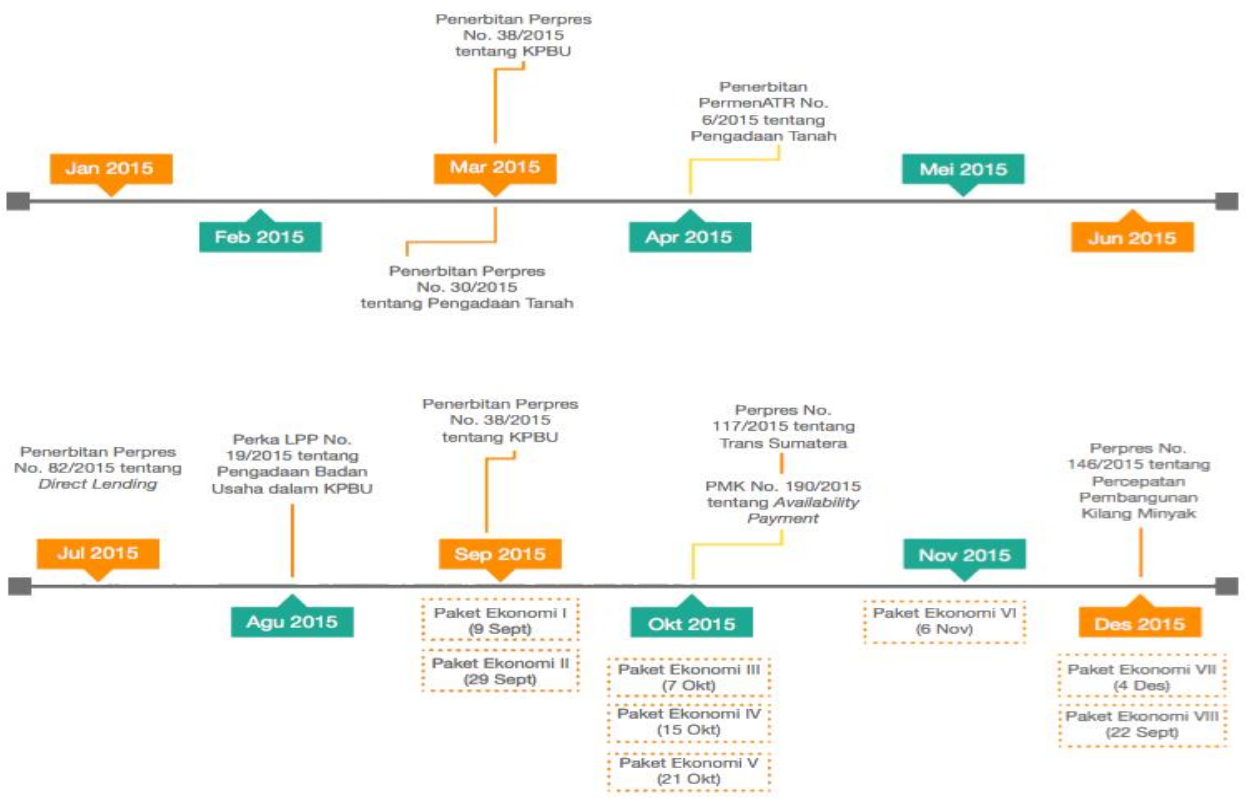

Gambar 1.1

\footnotetext{
1 Yang di maksud dengan Pergantian Pemerintahan adalah pergantian kekuasaan Presiden dari masa Presiden Susilo Bambang Yudhoyono (SBY) ke Presiden Joko Widodo (Jokowi), pergantian tersebut di mulai tahun 2014.
} 
Penguatan Hukum Pengadaan Barang Dan Jasa Pemerintah Untuk Mempercepat Pembangunan Indonesia

Perjalanan beberapa upaya percepatan Infrastruktur dengan menggunakan banyak peraturan. ${ }^{2}$

Dari gambar diatas, telah banyak perubahan-perubahan terkait aturan pengadaan barang dan jasa pemerintah, namun hanya terlihat pada bentuk aturan yang bersifat khsusus dan terpisah-pisah. Sejak di terbitkannya aturan mengenai pengadaan Barang dan Jasa Pemerintah, Peraturan yang di pakai pernah memiliki Legal Standing yang kuat berupa adanya Undang-Undang Nomor 18 Tahun 1999 Tentang Jasa Konstruksi. Akan tetapi saat ini Legal Standing mengenai hukum pengadaan barang dan jasa berubah menjadi hanya sebatas Keputusan Presiden (Kepres). ${ }^{3}$

Kekuatan Hukum pengadaan-pun baru mulai terganti dengan perubahan di tahun 2010, dimana Keppres yang sebelumnya terbit menggantikan Keppres pengadaan barang dan jasa pemerintah dalam kurun waktu 2003-2010, baru muncul jenis hukum yang lebih kuat dan mengikat dari Keppres yaitu Peraturan Presiden tepatnya pada masa Pemerintahan SBY. ${ }^{4}$

Padahal, melihat banyaknya perubahan isi dari peraturan tersebut sangat cocok diganti dengan jenis aturan yang secara hierarki perundang-undangan yang lebih tinggi dari sekedar Peraturan Presiden. Saat ini telah ada aturan terbaru mengenai hukum pengadaan barang dan jasa pemerintah, yakni Peraturan Presiden (Perpres) Nomor 16 tahun 2018.5

Melihat urgensi dan kebutuhan di lapangan, keberadaan Peraturan Presiden nomor 16 tahun 2018 perlu diganti dengan jenis peraturan yang lebih dari sekedar Peraturan Presiden. Pergantian tersebut bisa saja dirubah yang dahlunya adalah Peraturan Presiden menjadi sebuah Undang-Undang tentang pengadaan Barang dan Jasa Pemerintah. ${ }^{6}$ Penguatan Hukum pengadaan Barang dan Jasa Pemerintah akan menjadi pondasi yang kuat untuk mempercepat pembangunan yang merupakan salah satu prioritas pemerintah Indonesia. Untuk mengetahui pembahasan selanjutnya maka latar belakang diatas memberikan rumusan masalah adalah bagaiman politik kebijakan pengadaan barang dan jasa di Indonesia?

\subsection{Metode Penelitian}

Tulisan ini menggunakan kajian pustaka (literature research), dalam penelitian hukum metode ini dikatakan metode pendekatan yuridis normatif atau penelitian hukum kepustakaan yang

2 Perkembangan tentang peraturan Infrastruktur di Indonesia dalam https://kppip.go.id/tentangkppip/perkembangan-pembangunan-infrastruktur-di-indonesia/ diakses pada tanggal 20 Oktober 2019 Pukul 23.36 WIB.

${ }^{3}$ Coba lihat mengenai Keputusan Presiden (Keppres) Republik Indonesia Nomor 80 Tahun 2003 Tentang Pedoman Pelaksanaan Pengadaan Barang/Jasa Pemerintah yang masih berbentuk Keppres pada masa Pemerintahan Megawati Soekarno Putri.

${ }^{4}$ Coba lihat Peraturan Presiden (Perpres) No. 54 Tahun 2010 yang mengganti keputusan Presiden nomor 80 Tahun 2003.

${ }^{5}$ Peraturan Presiden Nomor 54 Tahun 2010 tentang Pengadaan Barang dan Jasa Pemerintah.

${ }^{6}$ Jika dalam keadaan ini, Presiden berposisi sebagai kepala pemerintah yang melakukan Tindakan hukum berupa recht handelingen, baca Muhtar Said, Asas Asas Hukum Administrasi Negara, Thafa Media, 2019 
Penguatan Hukum Pengadaan Barang Dan Jasa Pemerintah Untuk Mempercepat Pembangunan Indonesia

artinya suatu pendekatan berdasarkan aturan - aturan hukum sebagai suatu ketentuan yang abstrak atau dengan kata lain suatu cara atau prosedur yang digunakan untuk memecahkan masalah dengan mengadakan penelitian terhadap data sekunder. Fokus kajian terletak pada diskursus yang ada dalam teks, yakni norma tentang pengadaan barang dan jasa, baik yang diatur dalam undang-undang maupun dalam peraturan dibawahnya, terutama terkait dengan recht handelingen yang menjadi kewenangan Presiden

\section{P E M B A H A S A N}

\subsection{Sejarah Peraturan Pengadaan barang dan Jasa Pemerintah di Indonesia}

Pengadaan barang dan jasa menurut Perpres terbaru adalah kegiatan barang dan jasa oleh alat pemerintah dan penyedia (Kontraktor) mulai dari perencanaan, pengerjaan hingga serah terima pekerjaan hasil pengadaan. ${ }^{7}$ Tujuan dari pengadaan Barang dan jasa sendiri secara khusus dipergunakan untuk meningkatkan pelayanan publik. Pelayanan publik digunakan untuk melayani semua kebutuhan rakyat dalam bentuk fasilitas dan jasa yang masuk dalam sebuah program pengadaan barang dan jasa. Pelayanan publik menjadi kebutuhan dasar dalam bentuk pelayanan umum. ${ }^{8}$

Untuk membuat pelayanan umum tersebut menjadi semakin membaik dan tertib administrasi, tentu dibutuhkan sebuah aturan yang mengikat dan mengatur proses pengadaan barang dan jasa untuk membuat pelayanan publik baik dalam bentuk barang, jasa, infrastruktur dan bentuk lainnya. Proses pengadaan barang dan jasa tersebut menjadi hal yang sangat penting dalam memenuhi dan menyediaka sarana dan prasarana yang memadai. Aturan Pengadaan Barang dan jasa tidak lebih daripada memenuhi tujuan dari amanat Undang-Undang Dasar 1945 yaitu menciptakan masyarakat yang adil dan makmur.

Amanah Undang-Undang Dasar tersebut secara internasional dapat dimaknai oleh terselenggarakanya tata pemerintahan yang baik (Good Governance). Good Governance menurut dari UNDP (United Nations Development Program) adalah penyelenggaraan pemerintahan yang melibatkan banyak pihak seperti; Negara dan pemerintahan, Swasta, dan Masyarakat atau rakyat. ${ }^{9}$

Aturan yang mengatur mengenai pengadaan barang dan jasa pemerintah selanjutnya diatur dalam peraturan perundang-undangan. Pada awalnya dapat diambil kesimpulan bahwa peraturan perundang-undangan terkait barang dan jasa pemerintah telah ada pada tahun 1941.

\footnotetext{
${ }^{7}$ Peraturan Presiden (Perpres) nomor 16 Tahun 2018 tentang Pengadaan Barang/Jasa Pemerintah.

${ }^{8}$ Hardiyansyah. (2011). Kualitas Pelayanan Publik. Yogyakarta: Gava Media.

9 Sedarmayanti. (2009). Reformasi Administrasi Publik, Reformasi Birokrasi, dan Kepemimpinan Masa Depan: Mewujudkan Pelayanan prima dan Kepemerintahan yang baik. Bandung, Refika Aditama. Halaman 270.
} 
Penguatan Hukum Pengadaan Barang Dan Jasa Pemerintah Untuk Mempercepat Pembangunan Indonesia

Peraturan tersebut merupakan peraturan pemerintah kolonial Belanda yang dikenal dangan AV 41. AV 41 adalah Algemene voorwarden voor de uitvoering bij aanneming van openbare werken. Aturan ini mengatur mengenai cara dan syarat pembuatan konstruksi bangunan umum dan ditetapkan dengan sebuah surah keputusan pemerintah Kolonial Belanda pada tanggal 28 Mei 1941, surat keputusan dan aturan ini masih dalam bentuk bahasa Belanda, kemudian aturan ini menjadi aturan baku hingga dialihbahasakan ke dalam bahasa Indonesia. ${ }^{10}$

Aturan yang di kenal dengan AV.41 ini dibuat untuk mengatur segala bentuk hak dan kewajiban antara pengguna jasa serta penyedia jasa dalam mengerjakan jenis pekerjaan konstruksi umum. Aturan ini awalnya dibuat oleh perkumpulan pekerja konstruksi umum Hindia Belanda. Saat itu tidak ada orang pribumi yang menjadi bagian dari perkumpulan ini. Aturan yang dibuat ini kemudian menjadi dasar dan pedoman bagi para pelaku pengadaan saat itu, hingga sekarang dapat dikatakan jika aturan AV 41 itu menjadi dasar dari pengadaan barang dan jasa. AV 41 ini kemudian menjadi kekuatan hukum tetap hingga diperbaharui dengan aturan perundangundangan Undang-undang Nomor 18 Tahun 1999 Tentang Jasa Konstruksi dan dilanjutkan dengan Peraturan Pemerintah nomor 29 Tahun 2000 tentang penyelenggaraan jasa Konstruksi.

AV.41 tersebut kemudian tidak lagi menjadi dasar pengadaan barang dan jasa pemerintah di Indonesia karena telah diperbaharui dengan aturan yang baru. Proses pengadaan barang Jasa kemudian menjadi lebih sistematis dan banyak terdapat perbaikan-perbaikan, maka pada tahun 1999 lahirlah Undang-undang Nomor 18 Tahun 1999 Tentang Jasa Konstruksi. ${ }^{11}$ Undangundang Nomor 18 Tahun 1999 Tentang Jasa Konstruksi saat itu telah memiliki aturan dibawahnya berupa Peaturan Presiden, adapun diantara Peraturan presiden (Perpres) tersebut adalah:

- Peraturan Pemerintah Nomor 28 Tahun 2000 tentang Peran Serta Masyarakat Jasa Konstruksi.

- Peraturan Pemerintah Nomor 29 Tahun 2000 tentang Penyelengaraan Jasa Konstruksi.

- Peraturan Pemerintah Nomor 30 Tahun 2000 tentang Penyelenggaraan Pembinaan Jasa konstruksi.

Setelah itu barulah muncul aturan baru mengenai Pengadaan barang dan jasa pemerintah, tetapnya yang tertuang dalam Keputusan Presiden (Kepres) nomor 80 tahun 2003 tentang Pedoman Pelaksanaan Pengadaan Barang Jasa Pemerintah. Perbaikan Keputusan Presiden (Kepres) nomor 80 tahun 2003 tentang Pedoman Pelaksanaan Pengadaan Barang Jasa

10 Malangjoedo, Soekarsono Terbitan: (1978). "Algemene voorwaarden voor de uitvoering bij aaneming van openbare werken (AV 41 Algemene voorwaarden voor de uitvoering bij aanneming van openbare werken $=\mathrm{SU}$ 41: syarat-syarat umum untuk pelaksanaan bangunan umum yang dilelangkan). Jakarta: Badan Penerbit Pekerjaan Umum. 1983.

${ }^{11}$ Undang-undang Nomor 18 Tahun 1999 Tentang Jasa Konstruksi. 
Penguatan Hukum Pengadaan Barang Dan Jasa Pemerintah Untuk Mempercepat Pembangunan Indonesia

Pemerintah kemudian disempurnakan dengan lahirnya aturan baru berupa Peraturan Presiden (Perpres) Nomor 54 Tahun 2010 Tentang Pengadaan Barang/Jasa Pemerintah.

Peraturan ini lebih baik daripada peraturan sebelumnya karena terdapat beberapa perbaikan berupa inovasi sebagai pengganti pedoman atau acuan aturan pengadaan barang dan jasa pemerintah. Peraturan Presiden (Perpres) Nomor 54 tahun 2010 adalah salah satu Peraturan pengadaan Barang/Jasa yang sangat banyak perubahan dibandingkan dengan aturan sebelumnya.

Diantara perbaruan dan perubahannya dapat dilihat pada proses lelang yang merupakan salah satu hal penting dalam pengadaan barang dan jasa pemerintah, misalkan dalam proses pengumuman yang dilakukan dengan menunjukan pengumuman lelan melalui papan-papan pengumuman dan media cetak seperti Koran.

Kemajuan tersebut terlihat dengan adanya sistem baru yang sangat memudahkan penyedia dalam melihat paket-paket pengadaan. Sistem tersebut diumumkan dengan portal dan dilakukan secara elektronik melalui Layanan Pengadaan Secara Elektronik (LPSE). Kemudian terdapat perubahan lain dalam unsur pengadaan yang terpisah dan dapat di lihat melalui instansi-instansi terkait. Dalam instansi tersebut terdapat di ULP (Unit Layanan Terpadu). ULP ini merupakan lembaga yang memiliki panitia lelang dengan pokja-pokja yang terpisah-pisah di setiap instansi yang dimaksud. Disisi lain, proses yang terdapat pada Perpres 54 tahun 2010 semua dilakukan secara elektronik sehingga sangat terbuka dan memudahkan banyak pihak yang ingin mengetahui dan ikut terlibat dalam segala proses pengadaannya. Tidak lupa pula perubahan lainnya berupa pergantian sebutan misalnya; PimPro (Pemimpin Proyek) telah berubah menjadi PA (Pengguna Anggaran)/(KPA) Kuasa Penguna Anggaran/(PPK) Pejabat Pembuat Komitmen.

\subsection{Perbedaan Perpres 54 tahun 2010 dan Perspres 18 than 2018}

Perubahan terkait Peraturan Presiden (Perpres) nomor 54 tahun 2010 yang diagantikan dengan Peraturan Presiden (Perpres) nomor 18 tahun 2018 secara subtansi adalah menggantikan dan meperbaiki kekurangan sebelumnya. Secara sederhana terdapat beberapa perbedaan yang mudah dilihat diantara kedua peraturan tersebut, salah satunya adalah mengenai penandanangan kontrak. pada peraturan Presiden nomor 54 Tahun 2010, penanda tangan kontrak berada pada (PA) Pengguna Anggaran atau (KPA) Kuasa Pengguna Anggaran atau juga (PPK) Pejabat Pembuat Komitmen.

Penandatanagan kotrak tersebut didelegasikan kepada PA, KPA atau PPK tergantung dari jumlah kegiatan yang akan di tandatangani. Ini dilakukan dengan melihat pada kemampuan dalam menangani kegiatan pengadaan yang terbatas sehingga dibutuhkan pendelegasian kepada salah satu dari PA, KPA atau PPK.

Selain itu, Proses lelang juga dilakukan dengan ULP (Unit Layanan Pengadaan) yang sifatnya otonom. Proses lelang tersebut kemudian akan dibentuk Pokja-pokja sebagai badan yang bertanggungjawab jawab pada proses pengadaan. 
Penguatan Hukum Pengadaan Barang Dan Jasa Pemerintah Untuk Mempercepat Pembangunan Indonesia

Sedangkan dalam Peraturan Presiden (Perpres) nomor 16 Tahun 2018 tentang Pengadaan Barang/jasa Pemerintah, terdapat perubahan dari pelaksana-pelaksana kegiatan pengadaan. Salah satunya adalah PPHP (Pejabat Penerima Hasil Pekerjaan) yang tugas dan wewenangnya menerima hasil pengerjaan. Dua unsur yang terbaru tersebut adalah PPHPdan PjPHP atau Pejabat Pemeriksa Hasil Pekerjaan.

\section{KESIMPULAN DAN PENUTUP}

Peratuan mengenai Pengadaan barang dan jasa telah ada sebelum Indonesia merdeka tepatnya pada Algemene voorwarden voor de uitvoering bij aanneming van openbare werken atau lebih di kenal dengan AV 41.Aturan AV 41 tersebut kemudian diganti dengan Undang-Undang Nomor 18 Tahun 1999 Tentang Jasa Konstruksi. Auran tersebut juga dibantu dengan beberapa peraturan pemerintah berupa Peraturan Pemerintah Nomor 28 Tahun 2000 tentang Peran Serta Masyarakat Jasa Konstruksi, Peraturan Pemerintah Nomor 29 Tahun 2000 tentang Penyelengaraan Jasa Konstruksi, dan Peraturan Pemerintah Nomor 30 Tahun 2000 tentang Penyelenggaraan Pembinaan Jasa konstruksi. Perubahan aturan kemudian berganti dengan Keputusan Presiden (Kepres) nomor 80 tahun 2003 tentang Pedoman Pelaksanaan Pengadaan Barang Jasa Pemerintah dan diperbarui lagi dengan Peraturan Presiden (Perpres) Nomor 54 Tahun 2010 Tentang Pengadaan Barang/Jasa Pemerintah Terakhir muncul Perpres 16 tahun 2018 Tentang Pengadaan Barang/Jasa Pemerintah.

Perubahan Perpres 16 tahun 2018 Tentang Pengadaan Barang/Jasa Pemerintah sudah saatnya diganti dengan peraturan dengan Hierarki perundang-undangan yang lebih tinggi. Aturan tersebut bisa berupa Undang-undang layaknya Undang-Undang Nomor 18 Tahun 1999 Tentang Jasa Konstruksi yang pernah berlaku sebelumnya.Pembentukan Undang-undang pengadaan yang baru untuk menggantikan Perpres 16 tahun 2018 Tentang Pengadaan Barang/Jasa Pemerintah akan menjadi terobosan yang baik dan juga legal standing yang baik dalam mempercepat pembangunan infrastrukur sesuai dengan prioritas pemeintah dan penguatan pengadaan di Indonesia.

\section{BIBILIOGRAFI}

\section{a. Buku dan Jurnal}

Hardiyansyah. (2011). “Kualitas Pelayanan Publik”. Yogyakarta: Gava Media

Malangjoedo, Soekarsono Terbitan: (1978). "Algemene voorwaarden voor de uitvoering bij aaneming van openbare werken (AV 41 Algemene voorwaarden voor de uitvoering bij aanneming van openbare werken $=\mathrm{SU}$ 41: syarat-syarat umum untuk pelaksanaan bangunan umum yang dilelangkan). Jakarta: Badan Penerbit Pekerjaan Umum. 1983. 
Penguatan Hukum Pengadaan Barang Dan Jasa Pemerintah Untuk Mempercepat Pembangunan Indonesia

Sedarmayanti. (2009). "Reformasi Administrasi Publik, Reformasi Birokrasi, dan Kepemimpinan Masa Depan: Mewujudkan Pelayanan prima dan Kepemerintahan yang baik. Bandung”. Refika Aditama. Halaman 270.

\section{b. Peraturan Perundang-undangan}

Undang-Undang Nomor 18 Tahun 1999 Tentang Jasa Konstruksi.

Keputusan Presiden (Keppres) Republik Indonesia Nomor 80 Tahun 2003 Tentang Pedoman Pelaksanaan Pengadaan Barang/Jasa Pemerintah.

Peraturan Presiden (Perpres) Nomor 54 Tahun 2010 tentang Pengadaan Barang dan Jasa Pemerintah.

Peraturan Presiden (Perpres) nomor 16 Tahun 2018 tentang Pengadaan Barang/Jasa Pemerintah.

\section{c. Media online dan Website}

Perkembangan tentang peraturan Infrastruktur di Indonesia dalam https://kppip.go.id/tentangkppip/perkembangan-pembangunan-infrastruktur-di-indonesia/ diakses pada tanggal 20 Oktober 2019 Pukul 23.36 WIB. 